suggesting that fibre may be the active fraction. In experiment 3 , lucerne meal, oat hulls, beet pulp and wheat straw were compared, at the same level ( $7.8 \mathrm{p}$. Ioo) of dietary fibre. Only lucerne meal gave a greater growth rate $(P<0.5)$ than for the low fibre control diet. In experiment 4 , the effectiveness of finely ground lucerne meal vs lucerne hay ad libitum was compared. Both forms of lucerne gave improved growth $(\mathrm{P}<0.5)$.

In all but experiment 4 , inclusion of lucerne reduced the incidence of enteritis. It is concluded that lucerne meal, as a fibre source, improves growth and reduces enteritis in young rabbits.

\title{
Study of different protein sources for rabbit feeding
}

\author{
T. GIPPERT
}

Institute of small animal breeding

2 IOO Gödöllö (Hungary)

In a first experiment, the author studied the partial or total substitution of lucerne proteins by those of soyabean meal or milk powder in a balanced diet for growing rabbits. The addition of wheat straw maintained constant the crude fibre level of the diets ( 4 p. Ioo). In a second experiment, he compared the nutritive value for growing rabbits of the oil meals of soyabean, sunflower, rapeseed and linseed.

The author observed no real improvement of growth rate and feed conversion ratio after replacement of lucerne protein by soyabean proteins or milk proteins.

In the second experiment, the best performances were observed for soyabean (growth and feed conversion ratio), but they were not significantly different from those obtained with sunflower meal and rapeseed meal. With linseed meal, growth rate of rabbits was significantly reduced by $9 \mathrm{p}$. Ioo and feed conversion ratio increased by ro p. Ioo. No toxic effect was observed with rapeseed meal.

\section{Utilization of grape marc by growing rabbits}

\author{
R. PARIGI-BINI, G. M. CHIERICATO \\ Istituto di Zootecnica - Facolta di Agravia \\ Via Gradenigo, 6 - 3510o Padova (Italy)
}

This experiment was conducted to investigate the effects of grape marc (GM) in place of dehydrated lucerne meal (DLM) on diet utilization by growing rabbits.

Sixty young male rabbits (N. Z. White) were randomly divided into 6 groups and allocated in individual rearing or metabolism cages.

The animals were fed 6 different concentrate pelleted diets in which increasing quantities $\left(0,8, I_{6}, 24,32\right.$ and $40 \mathrm{p}$. Ioo) of GM were used in place of the same quantity of DLM.

The digestibility of DM, OM and especially that of CP was significantly depressed by the increasing level of GM, eventhough the crude fibre level of the diets was lowered by this replacement.

These results were explained by the chemical composition of GM, which was relatively low in crude fibre content, but particularly high in ADF and lignin fractions.

The digestibility depression did not negatively influence growth voluntary feed intake and feed efficiency, due to the higher crude protein and gross energy content of GM compared with that of DLM.

Moreover, the experimental diets were supplemented by sulphur amino acids and lysine. 